\title{
Klasyfikacja własności skał zbiornikowych przy użyciu metod uczenia maszynowego na podstawie danych geofizyki otworowej
}

\author{
Jan Barbacki (D)
}

AGH Akademia Górniczo-Hutnicza, Wydział Wiertnictwa, Nafty i Gazu, Kraków

\begin{abstract}
Streszczenie: W artykule przedstawiono możliwość wykorzystania wybranych metod uczenia maszynowego do automatycznej klasyfikacji własności skał zbiornikowych na podstawie profilowań geofizyki otworowej. Zaprezentowano schemat tworzenia inteligentnego modelu typu data-driven oraz opisano sposób przetwarzania (preprocessingu) danych złożowych. Omówiono i porównano także popularne algorytmy klasyfikacyjne: maszynę wektorów nośnych, drzewa decyzyjne, lasy losowe, metodę $k$-NN oraz sztuczne sieci neuronowe. Zaproponowane rozwiązanie może okazać się niezwykle przydatne w modelowaniu złóż węglowodorów, wspomagając i automatyzując ich analizę petrofizyczną oraz redukując niepewność wyników otrzymywanych z końcowego modelu symulacyjnego.
\end{abstract}

Słowa kluczowe: uczenie maszynowe, sztuczna inteligencja, klasyfikacja skały, facje, profilowania geofizyczne

\section{RESERVOIR ROCK CLASSIFICATION USING MACHINE LEARNING METHODS BASED ON WELL LOG DATA}

\begin{abstract}
The paper presents the possibility of using selected machine learning methods for automatic classification of reservoir rocks properties based on well-log data. The study presents fundamental concepts of a data-driven approach, as well as presents the detailed workflow for working with reservoir data. Popular classification techniques such as support vector machine, decision trees, random forests, $k$-NN and artificial neural networks are also discussed and compared. The proposed methodology can prove to be extremely useful in computer modeling of hydrocarbon reservoirs, supporting and automating their petrophysical analysis and reducing the uncertainty of results obtained from the final simulation model.
\end{abstract}

Keywords: machine learning, artificial intelligence, rock classification, facies, well logs

https://doi.org/10.7494/978-83-66727-48-9_1 


\section{Wstęp}

Poprawne określenie litologii ośrodka skalnego, a co za tym idzie - własności petrofizycznych skał zbiornikowych, ma kluczowe znaczenie w procesie opracowywania wiarygodnego modelu symulacyjnego złoża gazu ziemnego. Najwierniejszy opis geologiczny złoża można uzyskać dzięki kompleksowym badaniom laboratoryjnym rdzeni skalnych - rozwiązanie to stosowane jest jednak w ograniczonym zakresie ze względu na wysokie koszty badań, co w efekcie umożliwia prawidłową reprezentację własności złoża jedynie w niewielkim jego fragmencie. We wszystkich miejscach, w których nie zostały pobrane rdzenie wiertnicze, zastosowanie znajduje interpretacja danych geofizyki otworowej - łatwiejszych do pozyskania, a dzięki temu szerzej dostępnych. W ciągu ostatnich dekad przebadano szereg metod statystycznych pod kątem ich potencjalnego wykorzystania w analizie profilowań wiertniczych. Wolf i Pelissier-Combesecure (1982) zaprezentowali możliwość użycia analizy głównych składowych (PCA) do automatycznego wyznaczania facji, Busch i in. (1987) przedstawili zastosowanie analizy dyskryminacyjnej dla tego samego problemu, Baldwin i in. (1990) do klasyfikacji skały wykorzystali sztuczne sieci neuronowe, Saggaf i Nebrija (2003) natomiast - techniki rozmyte. Obiecujące wyniki przeprowadzonych prac przyniosły nie tylko dalsze zainteresowanie szerokim spektrum metod uczenia maszynowego, ale także utwierdziły badaczy, że możliwe jest takie powiązanie wyników badań laboratoryjnych z danymi geofizyki otworowej, aby w efekcie umożliwić w pełni automatyczne i skuteczne wnioskowanie o składzie skalnym w miejscach, w których rdzenie wiertnicze nie zostały pobrane.

\section{Uczenie maszynowe}

Uczenie maszynowe (machine learning) jest obecnie najintensywniej rozwijanym obszarem sztucznej inteligencji. Dział ten zajmuje się metodami umożliwiającymi imitację inteligentnego zachowania przez uczenie się na podstawie danych bez jawnego zaprogramowania - jest to więc podejście autonomiczne, sterowane danymi (data-driven approach). Głównymi zagadnieniami uczenia maszynowego są problemy regresyjne, klasyfikacyjne oraz klasteryzacyjne (Raschka i Mirjalili 2019). Celem metod regresyjnych jest predykcja wartości na podstawie ciągu danych, np. wyznaczanie zasobów wydobywalnych na podstawie szczegółowego opisu złoża (Nagy i in. 2019) czy też prognoza wydobycia gazu ze złoża na podstawie danych historycznych (Klimkowski i in. 2019). Metody klasyfikacyjne koncentrują się wokół problemu przypisania nowego, nieznanego przypadku (np. danych geofizyki otworowej w badanym interwale głębokościowym) do zdefiniowanej wcześniej klasy (np. litofacji lub innej jednostki grupującej) (Singh i in. 2020). Zadaniem metod klasteryzacyjnych jest natomiast znalezienie podobienstwa pomiędzy danymi w zbiorze, umożliwiającego wydzielenie maksymalnie jedno- 
rodnych klas (zwanych też grupami lub klastrami), np. odseparowanie stref w złożu o diametralnie różnych właściwościach petrofizycznych (Xu i in. 2019). Zagadnienia klasyfikacyjne i klasteryzacyjne są względem siebie komplementarne (rys. 1).

a)

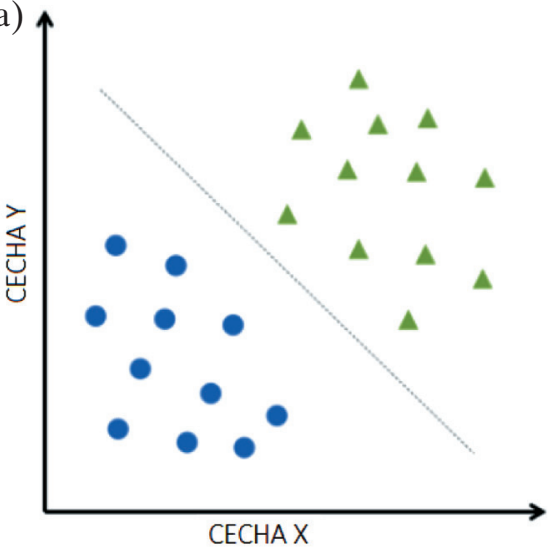

b)

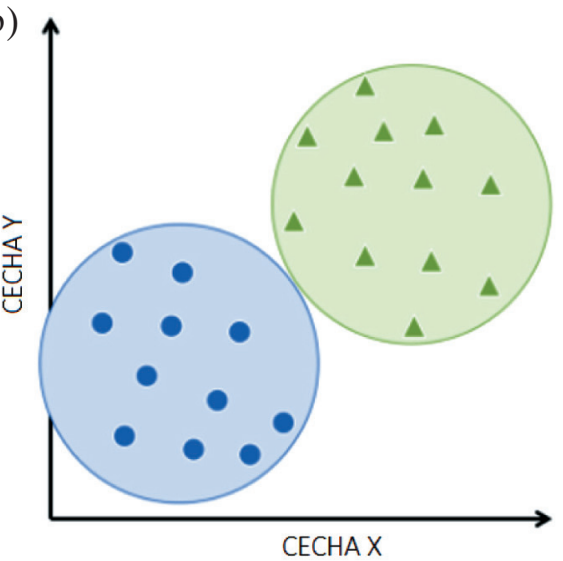

Rys. 1. Klasyfikacja (a) - znaleziona granica decyzyjna, która umożliwia przypisanie nieznanej próbki do klasy; klasteryzacja (b) - podział na grupy; liczba klastrów może być wstępnie przyjęta lub całkowicie nieznana

Źródło: opracowanie własne na podstawie Lee (2020)

\section{Automatyczna klasyfikacja facji}

$\mathrm{Na}$ potrzeby zaprezentowania możliwości automatycznego określania litologii złoża w pobliżu wybranego odwiertu wykorzystano zestaw danych ze złoża suchego gazu ziemnego w południowo-wschodniej części stanu Kansas w Stanach Zjednoczonych (Hall 2016). Zbiór ten składa się z siedmiu atrybutów (pięć geofizycznych: profilowania gamma, opornościowe, efektu fotoelektrycznego, porowatości neutronowej, gęstości objętościowej i dwie pomocnicze zmienne wskaźnikowe - stratygraficzne) oraz kolumny z etykietami określającymi typ skały na danej głębokości. Pomiary zostały wykonane dla dziewięciu odwiertów w zbliżonych interwałach głębokościowych i z identycznym krokiem o długości ok. 0,15 m (0,5ft). Podzbiór pomiarów na każdej głębokości nosi nazwę wektora cech i jest ściśle powiązany z klasą (w opisywanym przypadku: z litofacją). Przez fację (litofację) należy rozumieć taką wydzieloną jednostkę litologiczną, która grupuje skały o podobnych cechach litologicznych (a więc o zbliżonym składzie mineralnym, strukturze oraz uziarnieniu). W zbiorze danych zidentyfikowano dziewięć klas (facji): piaskowca, mułowca, wapienia, dolomitu i łupka, które nie są jednak całkowicie odrębne - niektóre z nich „nachodzą na siebie”, tworząc tzw. facje sąsiadujące. Pojedyncza próbka mogłaby zostać przypisana do dwóch różnych klas; jej ostateczna etykieta jest wynikiem arbitralnej decyzji twórcy bazy danych. 
Można więc się spodziewać, że w przypadku sąsiadujących facji wystąpi ich błędna klasyfikacja - jest to jednak sytuacja typowa dla danych rozmytych, w których granice pomiędzy zbiorami są nieostre, co oddaje ich niepewność (Dubois i in. 2007).

Problem przypisania facji na podstawie danych geofizyki otworowej jest problemem klasyfikacyjnym - do znalezienia granic decyzyjnych pomiędzy zarejestrowanymi próbkami, umożliwiających późniejszą klasyfikację nowych przypadków (tj. niebiorących udziału w procesie uczenia), wykorzystano metodę maszyny wektorów nośnych (Support Vector Machine, SVM). Technika ta, w dużym uproszczeniu, polega na znalezieniu takiej granicy decyzyjnej pomiędzy skupiskami, dla której odległość skrajnych punktów skupisk (zwanych wektorami nośnymi - stąd nazwa metody) od tej granicy jest taka sama i możliwie jak największa (Flasiński 2011). Granica ta jest zawsze podprzestrzenią (hiperpłaszczyzną) o wymiarze o jeden mniejszym niż przestrzeń nadrzędna. Przykładowo dla danych opisanych dwoma atrybutami granicą decyzyjną byłaby linia prosta (rys. 2); w przypadku opisywanym w niniejszym artykule granica decyzyjna jest hiperpłaszczyzną o sześciu wymiarach - niemożliwe jest więc jej przedstawienie w formie graficznej bez utraty wymiarów.

a)

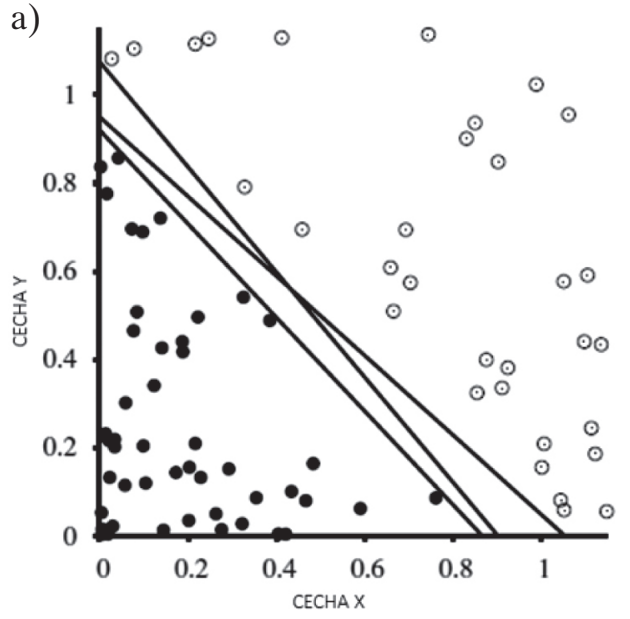

b)

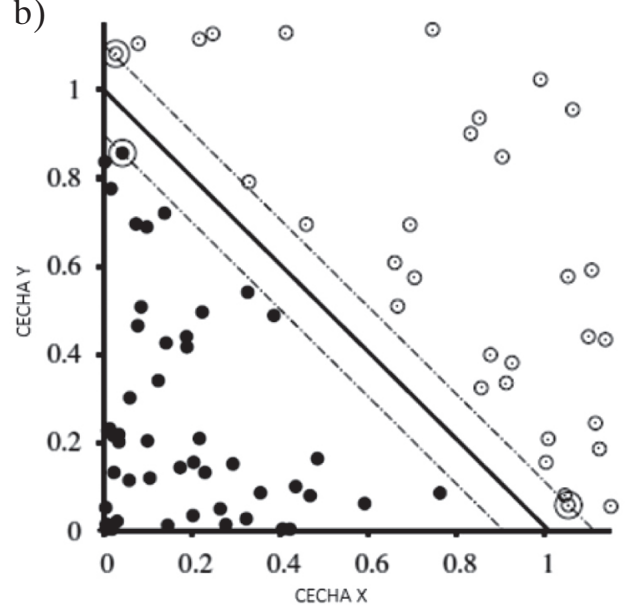

Rys. 2. Dwie klasy (czarne i białe punkty) oraz przykład trzech możliwych granic decyzyjnych (a); granica decyzyjna (linie przerywane) z największą odległością od wektorów nośnych (punkty otoczone okręgiem) (b)

Źródło: opracowanie własne na podstawie Russell i Norvig (2010)

Zbiór danych, w których skład wchodzą wszystkie próbki, dzielony jest na podzbiory danych uczących i danych testowych. W procesie uczenia, tj. dostrajania parametrów modelu, tak aby model generował poprawne odpowiedzi, biorą udział tylko dane uczące - dane testowe są na tym etapie „niewidoczne” i służą wyłącznie do sprawdzenia poprawności pracy klasyfikatora. Na rysunku 3 zaznaczono zbiory: uczaccy (osiem odwiertów) i testowy (jeden odwiert). 


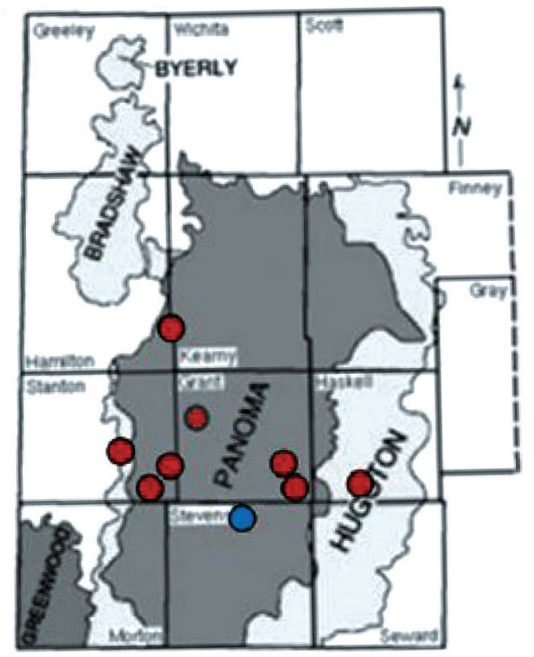

Rys. 3. Dane z ośmiu odwiertów stanowią zbiór uczący (czerwony kolor), natomiast dane $\mathrm{z}$ jednego, losowo wybranego odwiertu stanowią zbiór testowy (niebieski kolor) Źródło: Mohamed i in. (2019)

Zarówno zbiór uczący, jak i testowy poddaje się procesowi standaryzacji, tj. takiego przeskalowanie danych, aby średnia wartość oczekiwana każdej cechy wynosiła 0 , a wariancja była równa 1; operacja ta, choć nie jest niezbędna, jest zazwyczaj wskazana do stworzenia poprawnie działających klasyfikatorów (Géron 2017). Następnie przy użyciu darmowych, otwartych i ogólnodostępnych bibliotek programistycznych, takich jak pakiet SciPy dostępny dla języka Python, tworzony jest wstępny model klasyfikatora, tj. taki model, w którym parametry charakteryzujące proces uczenia dobierane są w sposób losowy albo - najlepiej - w sposób świadomy, bazujący na doświadczeniu eksperta z zakresu uczenia maszynowego. Kolejnym, najważniejszym i najbardziej czasochłonnym, krokiem jest proces dostrajania wartości hiperparametrów modelu, bezpośrednio odpowiedzialnych za przebieg proces uczenia. W tym celu ze zbioru uczącego wydziela się podzbiór walidacyjny, będący swego rodzaju zbiorem semitestowym. Dla obu tych podzbiorów (uczącego i walidacyjnego) poszukuje się takich wartości hiperparametrów, w przypadku których błąd klasyfikacji jest możliwie najmniejszy.

W opisywanym przypadku do badań numerycznych mających na celu znalezienie najlepszego klasyfikatora wybrane zostały dwa parametry: regularyzacji $(C)$ oraz gamma. Odpowiadają one za poziom dopasowania modelu do danych uczących. Niskie wartości współczynników $C$ i gamma oznaczają duży margines błędów klasyfikatora (a więc jego większe uogólnienie); wysokie wartości oznaczają większe dopasowanie klasyfikatora do danych. Obie skrajności są niepożądane i skutkować będą błędnym działaniem podczas procesu klasyfikacji. W wyniku serii eksperymentów numerycznych wyznaczone zostały możliwie najlepsze wartości hiperparametrów $C$ i gamma (rys. 4). 

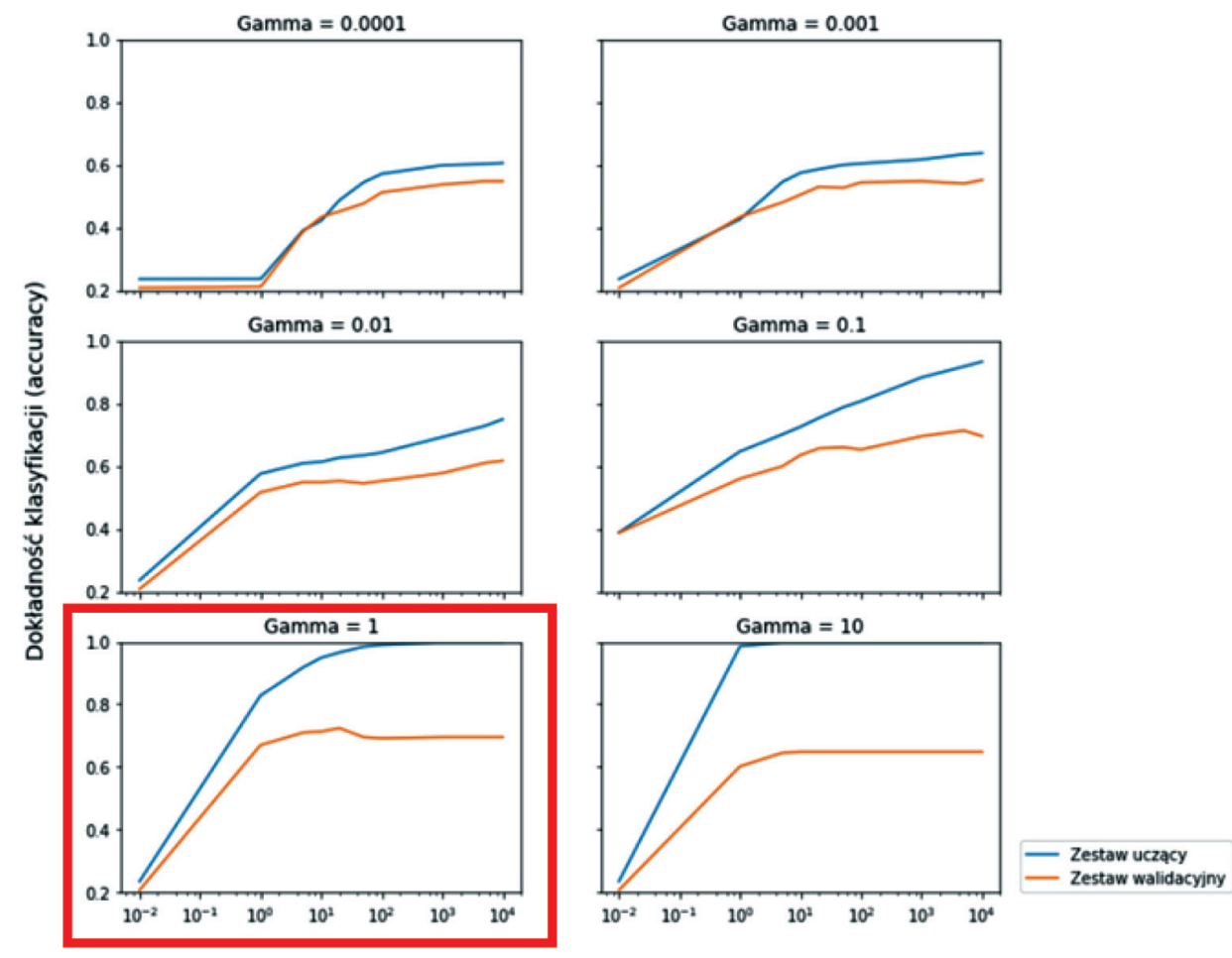

Parametr C

Rys. 4. Dobór optymalnych wartości hiperparametrów regularyzacji $(C)$ oraz współczynnika gamma. Najlepszy zestaw wartości został oznaczony czerwoną ramką Źródło: opracowanie własne na podstawie Hall (2016)

Ostatnim etapem jest przetestowanie wytrenowanego klasyfikatora na zbiorze testowym, niewidocznym na etapie tworzenia modelu (blind data). W tym celu na wejście stworzonego modelu podaje się ciąg danych geofizyki otworowej na danej głębokości, w efekcie otrzymując decyzję klasyfikacyjną, tj. obliczoną fację. Wielokrotne powtórzenie tej operacji umożliwia stworzenie przekroju litologicznego ośrodka, w miejscu, dla którego brak jest danych pochodzących z badań laboratoryjnych rdzeni skalnych (rys. 5). Model SVM stworzony według zaprezentowanej metodyki umożliwia uzyskanie dokładności klasyfikacyjnej facji zbliżonych na poziomie $87,75 \%$, co pokazuje, że klasyfikator oparty na uczeniu maszynowym może być skutecznym narzędziem wspomagającym proces określania litologii złoża, szczególnie w przypadku posiadania niewielkiej ilości danych z badań laboratoryjnych. Jakość działania klasyfikatorów zależy jednak od przyjętych wartości hiperparametrów - dostrajanie tych wartości wymaga przemyślanej strategii i doświadczenia, jest to proces trudny, choć w dłuższej perspektywie opłacalny, ponieważ poprawnie przygotowany klasyfikator może niemal w pełni zautomatyzować proces określania składu skalnego ośrodka. 


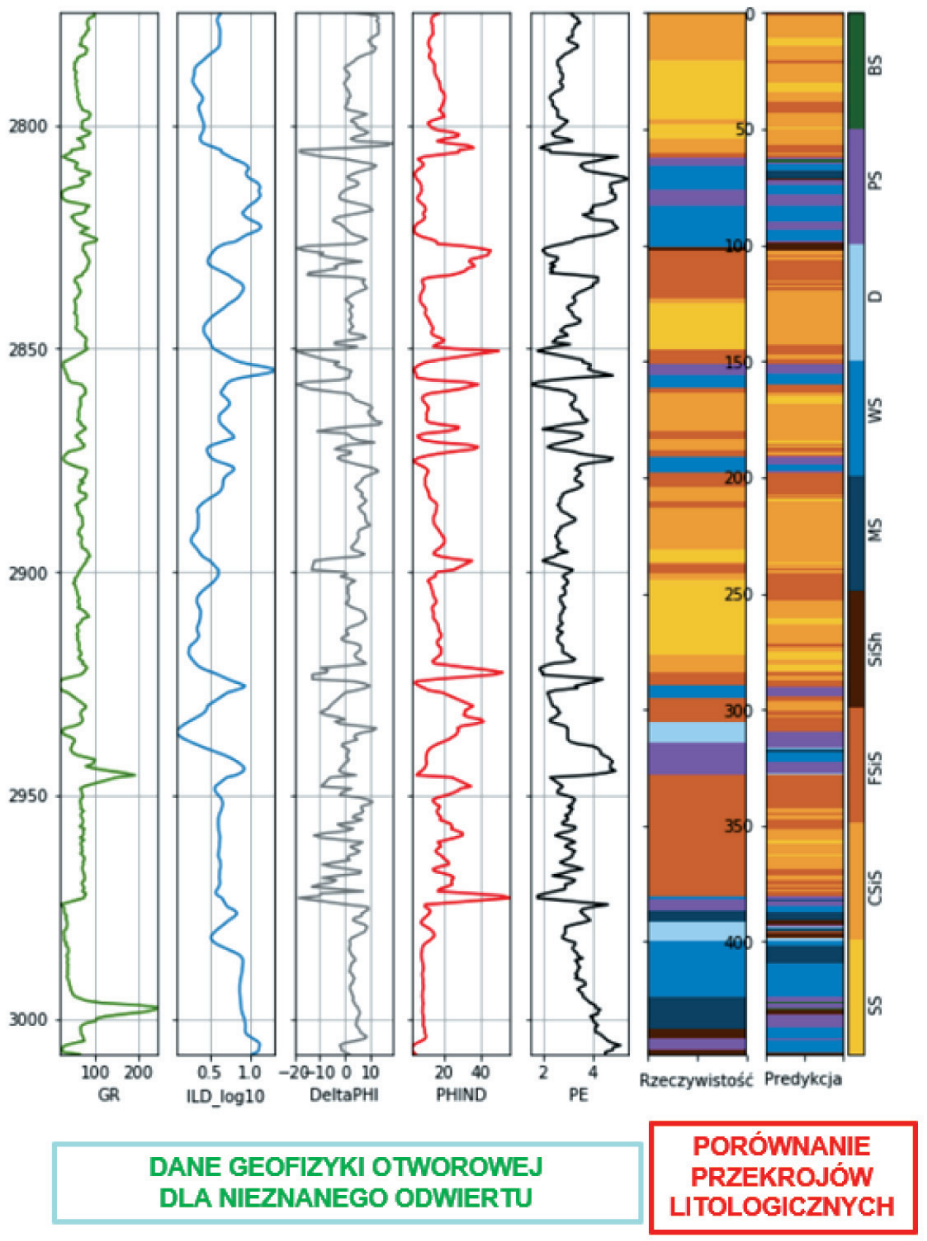

Rys. 5. Wynik działania klasyfikatora - widoczne dane wejściowe (profilowania geofizyki otworowej, pięć pierwszych kolumn) oraz dane wyjściowe (przekroje litologiczne, dwie ostatnie kolumny: zarówno wartości oczekiwane, jak i uzyskane)

Źródło: opracowanie własne na podstawie Hall (2016)

Opisany powyżej schemat tworzenia inteligentnego modelu typu data-driven został przedstawiony na rysunku 6. Jest to procedura uniwersalna, można więc ją zastosować do budowy klasyfikatora bazującego na dowolnym innym modelu, takim jak: drzewa decyzyjne, lasy losowe, metoda $k$-NN czy sztuczne sieci neuronowe. Metody mogą być stosowane wymiennie; dla tego samego zbioru danych klasyfikatory wykazują różną choć często do siebie zbliżoną - dokładność (rys. 7). Do oceny, który ze stworzonych modeli jest najlepszy, używa się różnych miar klasyfikatorów. Do najpopularniejszych należą: precyzja (precision), pełność (recall), dokładność (accuracy) oraz wskaźnik F1, będący kompromisem pomiędzy precyzją a pełnością (Géron 2017). 


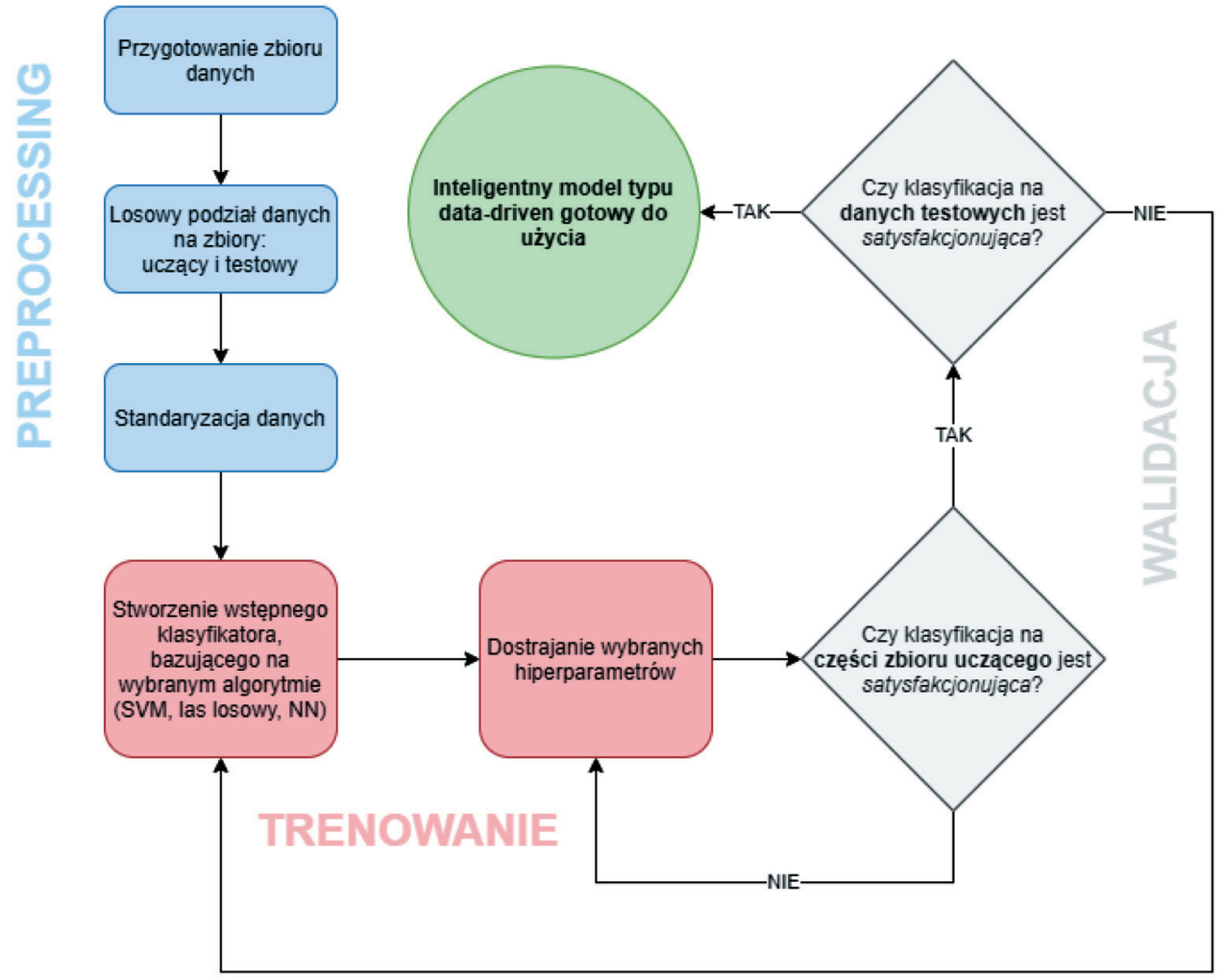

Rys. 6. Schemat tworzenia inteligentnego modelu typu data-driven do klasyfikacji litofacji na podstawie danych geofizyki otworowej

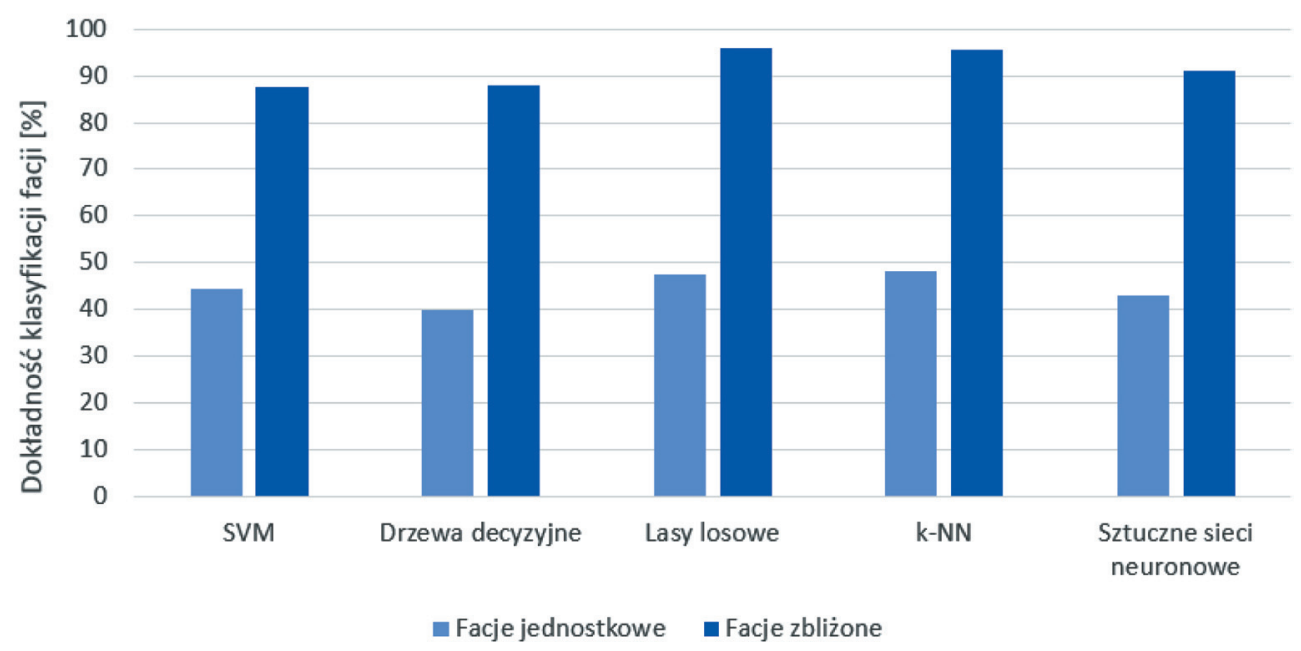

Rys. 7. Porównanie dokładności (accuracy) działania klasyfikatorów

w procesie automatycznego wyznaczania litofacji na podstawie danych geofizyki otworowej 


\section{Metoda drzew decyzyjnych}

Klasyfikacja za pomocą drzew decyzyjnych jest metodą sekwencyjnego rozpoznawania wzorców, w której przypisanie przypadku do klasy odbywa się w sposób wieloetapowy (Flasiński 2011). Drzewo decyzyjne jest acyklicznym grafem, w którym każdy wierzchołek węzeł zawiera warunek logiczny dla wybranego atrybutu wektora wartości cech, zaś wierzchołki liście przechowują decyzję klasyfikacyjną (etykietę). Przykład drzewa klasyfikacyjnego dokonującego etapowego podziału przestrzeni cech przedstawiono na rysunku 8.

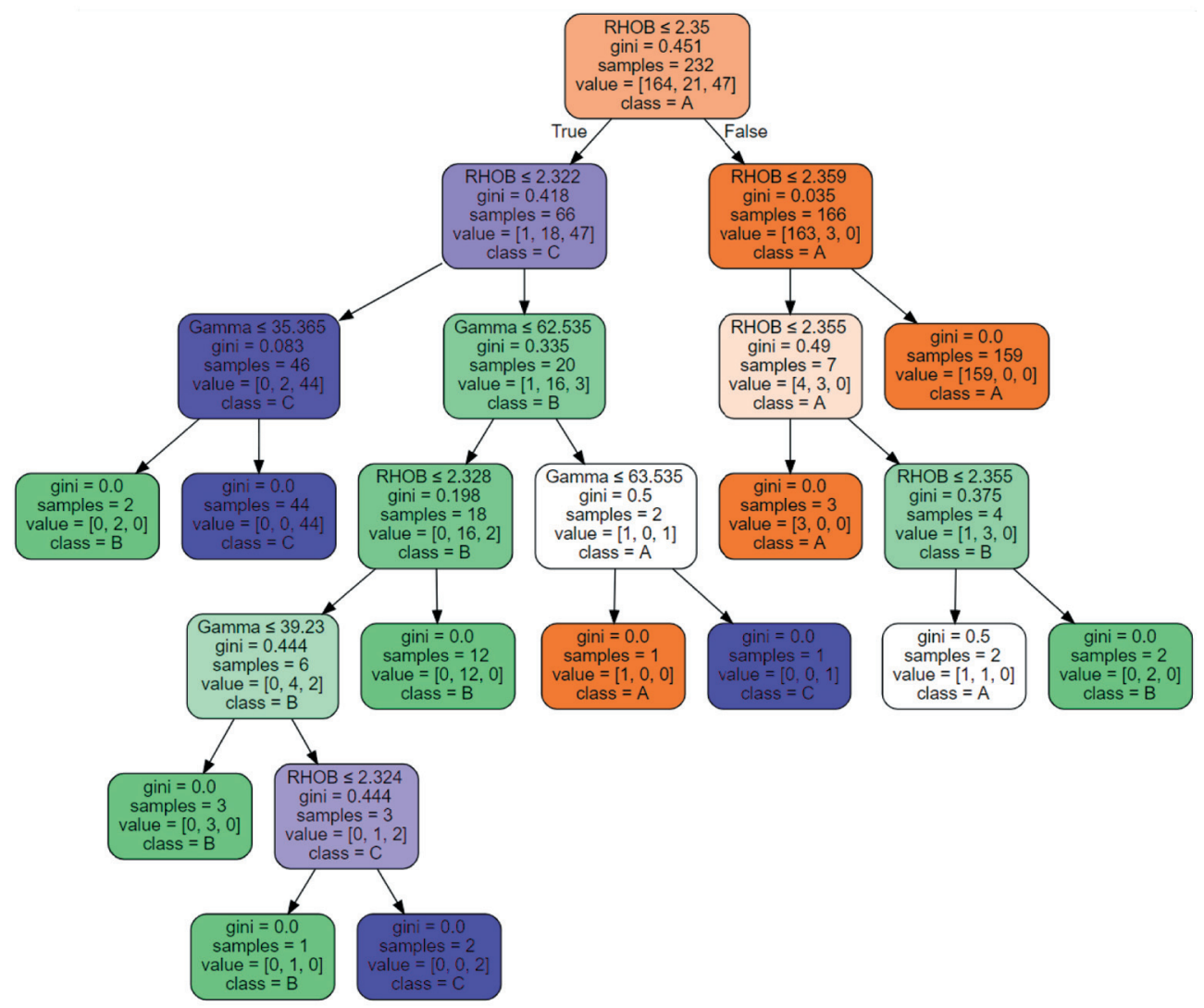

Rys. 8. Przykładowe drzewo decyzyjne dla danych geofizyki otworowej

(profilowania gamma i gęstości objętościowej) ze złoża ropy naftowej w Wirginii Zachodniej

(Stany Zjednoczone)

Konstrukcja optymalnego drzewa decyzyjnego jest problemem niemożliwym do rozwiązania w czasie wielomianowym (niewielki wzrost liczby przypadków uczących skutkuje znacznym wzrostem czasu obliczeń). Istnieje jednak wiele algorytmów umożliwiających szybką budowę akceptowalnego drzewa klasyfikacyjnego, wśród których do najpopularniejszych zalicza się metody CART (Classification and Regression Trees) 
oraz ID3 (Iterative Dichotomiser 3). Ogólny schemat budowy drzewa rozpoczyna się od wyboru, czy tworzony wierzchołek ma być liściem czy węzłem. W przypadku gdy tworzony jest liść, zostaje mu przypisana odpowiednia etykieta kategorii, natomiast kiedy tworzony jest węzeł, przypisany zostaje mu warunek logiczny (test), którego wynikom odpowiadają gałęzie prowadzące do poddrzewa tworzonego według tego samego schematu. Rozwiązanie to implementowane jest w postaci rekurencyjnej; różnice pomiędzy poszczególnymi metodami dotyczą kwestii doboru kryterium stopu oraz testu dla węzła (Cichosz 2007).

\section{Metoda lasów losowych}

Metoda lasów losowych należy do klasy algorytmów grupowych, w których przez połączenie wielu prostych klasyfikatorów (weak learners) tworzony jest kolejny, silny klasyfikator (strong learner). Do utworzenia lasu losowego złożonego z drzew klasyfikacyjnych wykorzystywana jest metoda bagging - drzewa są niezależne od siebie i mają tę samą wagę, a wynikiem działania klasyfikatora jest dominanta (najczęściej występująca wartość) klas wykrytych przez poszczególne drzewa (Esposito D. i Esposito F. 2020). Zaletą techniki losowych lasów decyzyjnych jest redukcja wariancji oraz zwiększenie stabilności modelu klasyfikacyjnego. Przykład lasu losowego wraz z uproszczonym schematem wnioskowania przedstawiono na rysunku 9.

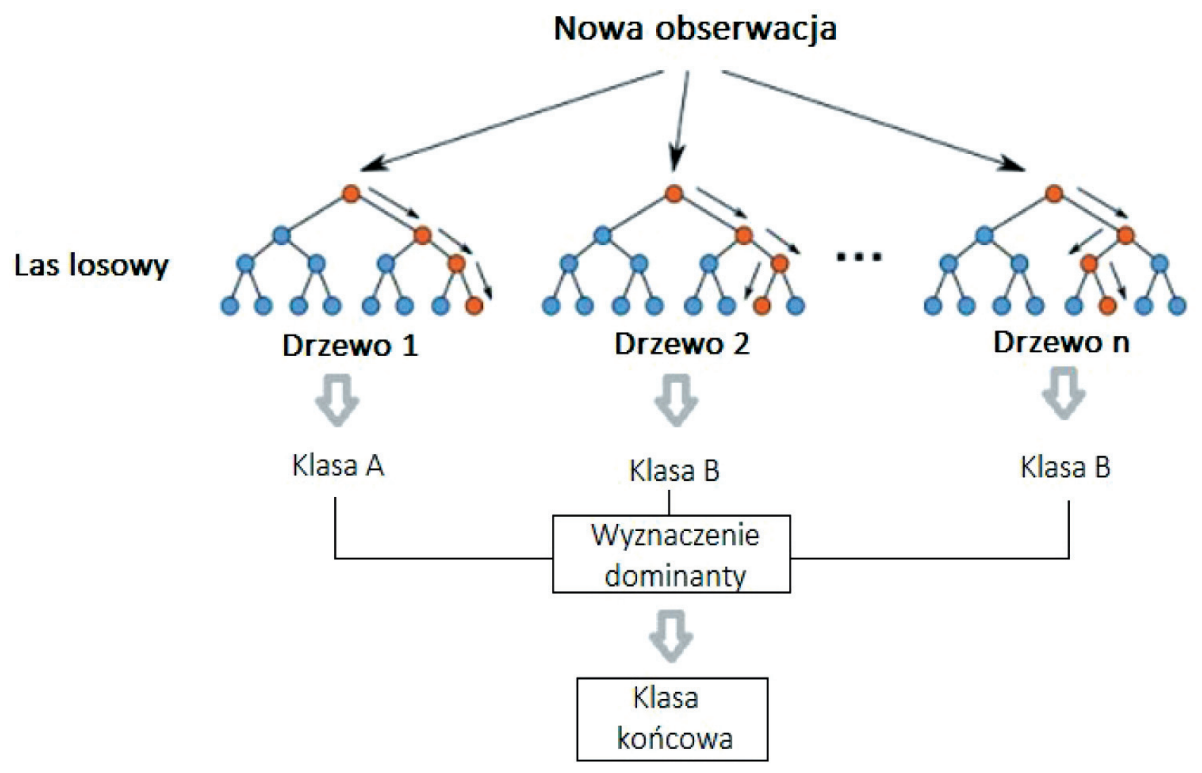

Rys. 9. Schemat klasyfikacji za pomocą lasu losowego zbudowanego $\mathrm{z}$ wielu różnych drzew decyzyjnych

Źródło: opracowanie własne na podstawie Jagannath (2020) 


\section{Metoda $k$-najbliższych sąsiadów}

Metoda $k$-najbliższych sąsiadów ( $k$-Nearest Neighbors, $k$-NN) jest algorytmem typu nieparametrycznego (instance-based learning algorithm), w którym konstrukcja klasyfikatora odbywa się przy użyciu wszystkich danych uczących, już podczas samej procedury klasyfikacji (Raschka i Mirjalili 2019).

Algorytm przebiega w następujących krokach:

1. wybór liczby $k$ oraz miary odległości (metryki);

2. obliczenie odległości pomiędzy klasyfikowaną obserwacją a wszystkimi pozostałymi (tj. znajdującymi się w zbiorze danych uczących);

3. wybór $k$ obserwacji leżących w najmniejszej odległości do klasyfikowanego przypadku;

4. przypisanie klasyfikowanej obserwacji tej klasy, która ma największą liczebność pośród $k$ najbliższych sąsiadów.

Skuteczność działania algorytmu $k$-NN, przez którą rozumie się poprawność klasyfikacji nowych obserwacji, w największym stopniu zależy od doboru odpowiedniej wartości parametru $k$ (rys. 10) oraz metryki. Parametry te dobierane są eksperymentalnie. Niska wartość parametru $k$ sprawia, że algorytm jest podatny na szumy występujące w danych; wysoka wartość parametru $k$, choć nie powoduje zwiększenia czasu obliczeń, niekoniecznie wpływa na poprawę samej klasyfikacji (Bishop 2006, Esposito D. i Esposito F. 2020). Jednym z proponowanych rozszerzeń klasycznego algorytmu $k$-NN jest zastosowanie wag w celu wyróżnienia tych atrybutów, które w klasyfikacji mają większe znaczenie (Duda i in. 2000).

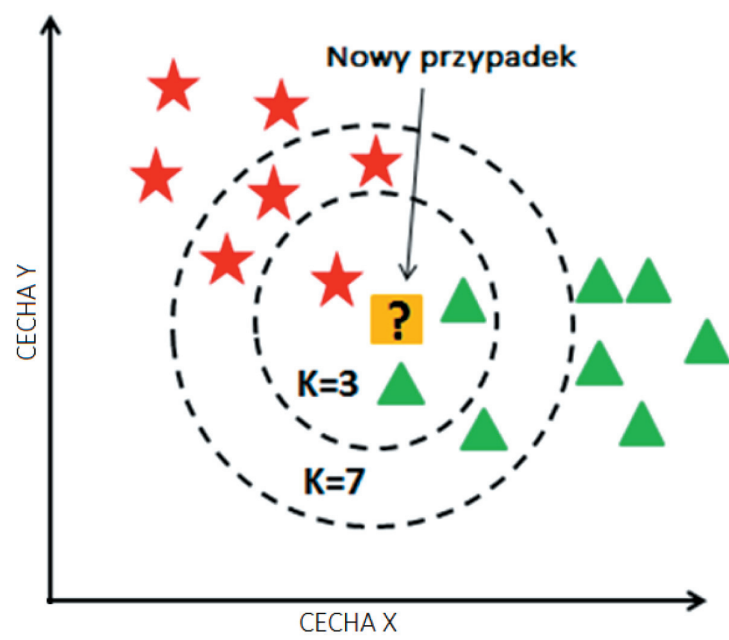

Rys. 10. Przypisanie nowego przypadku do klasy, zależnie od wybranej liczby sąsiadów (parametr $k$ )

Źródło: opracowanie własne na podstawie Navlani (2018) 


\section{Metoda sztucznych sieci neuronowych}

Sztuczne sieci neuronowe są modelami zainspirowanymi budową ludzkiego mózgu (Flasiński 2011), opartymi na modelu sztucznego neuronu, będącym analogią do biologicznego neuronu. Sztuczny neuron przyjmuje przychodzące do niego sygnały (stanowiące odpowiednik impulsów nerwowych), reprezentowane jako wektor wejściowy. Następnie sygnały przemnażane są przez wagi synaptyczne, reprezentowane jako wektor wag, określające moc każdego z połączeń i pełniące tę samą funkcję regulacyjną co synapsy neuronu biologicznego. Mnożenie sygnałów przez wagi skutkuje wzmocnieniem bądź osłabieniem sygnałów docierających do neuronu. Tak przetworzone sygnały poddawane są operacji sumowania, dając w efekcie jeden sygnał całkowitego pobudzenia. W ostatnim kroku całkowite pobudzenie wprowadzane jest jako wejście do funkcji aktywacji, weryfikującej czy sygnał osiągnął wartość progową, niezbędną do aktywacji sztucznego neuronu. Funkcja aktywacji generuje sygnał wyjściowy, będący odpowiedzią neuronu, który przekazywany jest dalej - do innego neuronu lub jako sygnał wyjściowy z sieci. Sztuczne neurony mogą być łączone ze sobą, tworząc sztuczne sieci neuronowe (SNN). Wyróżnia się różne architektury sztucznych sieci, wśród których do najpowszechniej używanych należą wielowarstwowe sieci jednokierunkowe, rekurencyjne sieci neuronowe oraz konwolucyjne sieci neuronowe (Chollet 2019). Zarówno pojedynczy neuron, jak i cała sieć neuronowa mogą być poddawane procesowi uczenia. W ogólnym ujęciu proces uczenia polega na takiej modyfikacji wag układu, aby błąd uzyskiwanej dla wzorcowych sygnałów (ciągów uczących) odpowiedzi mieścił się w akceptowalnym zakresie. Cechą charakterystyczną wielowarstwowych sieci jednokierunkowych jest organizacja neuronów w warstwy, z których pierwsza jest zawsze warstwą wejściową, a ostatnia - warstwą wyjściową, oraz ustalony kierunek przepływu sygnałów (od wejścia do wyjścia). Podstawowym problemem występującym w fazie projektowania sieci neuronowej jest dobór liczby warstw oraz liczby neuronów w każdej warstwie. Zazwyczaj oba te parametry są początkowo dobierane intuicyjnie, na podstawie doświadczenia projektanta sieci, a następnie modyfikowane z uwzględnieniem wyników podawanych przez sieć.

\section{Podsumowanie i wnioski}

W niniejszym artykule zaprezentowano praktyczny przypadek, obrazujący możliwość wykorzystania metod uczenia maszynowego w aspekcie wsparcia procesu modelowania złoża gazu ziemnego, wraz z zarysem potencjalnego rozszerzenia o różne algorytmy sztucznej inteligencji (SVM, drzewa decyzyjne, lasy losowe, metoda $k$-NN, sztuczne sieci neuronowe). Techniki te są niezwykle przydatne w szybkiej klasyfikacji skał, ułatwiając i automatyzując przygotowanie statycznego i dynamicznego modelu 
złoża, szczególnie w sytuacji, gdy brak jest wystarczającej ilości danych pochodzących z badań laboratoryjnych rdzeni skalnych. Ponadto dzięki równoczesnemu zastosowaniu różnych algorytmów klasyfikacyjnych w procesie automatycznej analizy danych geofizyki otworowej możliwe jest znaczące ograniczenie niepewności wyników otrzymywanych za pomocą końcowego modelu symulacyjnego. W efekcie użycie inteligentnych metod skutkuje uwiarygodnieniem modelu, czyniąc go rzeczywiście użytecznym i gotowym do dalszych analiz.

Przedstawione w artykule rozważania umożliwiają sformułowanie następujących wniosków:

1. Metody sztucznej inteligencji są przydatne w klasyfikacji facji skał zbiornikowych, wspomagając i automatyzując analizę petrofizyczną złóż węglowodorów.

2. Wytrenowany klasyfikator umożliwia natychmiastowe określenie składu skalnego w miejscu, w którym nie zostały pobrane do badań laboratoryjnych rdzenie wiertnicze.

3. Inteligentny model umożliwia tworzenie wiarygodnych modeli symulacyjnych na podstawie weryfikacji analiz bazujących na wiedzy eksperckiej.

4. Modele sterowane danymi są skalowalne i samoadaptujące się - wraz z rosnącym zbiorem danych znacząco zwiększa się ich wydajność, dzięki czemu można je wielokrotnie stosować na różnych etapach eksploatacji złoża.

5. Równoczesne zastosowanie różnych algorytmów klasyfikacyjnych w procesie automatycznej analizy profilowań wiertniczych sprzyja redukcji niepewności wyników otrzymywanych za pomocą końcowego modelu symulacyjnego.

\section{Literatura}

Baldwin J.L., Bateman R.M., Wheatley C.L., 1990, Application of a neural network to the problem of mineral identification from well logs, The Log Analyst, vol. 31(05), SPWLA-1990-v31n5a1.

Busch J.M., Fortney W.G., Berry L.N., 1987, Determination of lithology from well logs by statistical analysis, Society of Petroleum Engineers Formation Evaluation, vol. 2(04), s. 412-418. https://doi.org/10.2118/14301-PA.

Bishop C.M., 2006, Pattern Recognition and Machine Learning, Springer-Verlag New York.

Chollet F., 2018, Deep Learning with Python, Manning Publications.

Cichosz P., 2007, Systemy uczace się, Wydawnictwa Naukowo-Techniczne, Warszawa.

Dubois M.K., Bohling G.C., Chakrabarti S., 2007, Comparison of four approaches to a rock facies classification problem, Computers \& Geosciences, vol. 33(5), s. 599-617. https://doi.org/10.1016/j.cageo.2006.08.011.

Duda R.O., Hart P.E., Stork D.G., 2000, Pattern Classification, Wiley-Interscience. Esposito D., Esposito F., 2020, Introducing Machine Learning, Pearson Education. 
Flasiński M., 2011, Wstęp do sztucznej inteligencji, Wydawnictwo Naukowe PWN, Warszawa.

Géron A., 2017, Hands-On Machine Learning with Scikit-Learn and TensorFlow, O'Reilly Media.

Hall B., 2016, Facies classification using machine learning, The Leading Edge, vol. 35(10), s. 818-924. https://doi.org/10.1190/tle35100906.1.

Jagannath V., 2020, Random Forest Template for TIBCO Spotfire ${ }^{\circledR}$, https://community. tibco.com/wiki/random-forest-template-tibco-spotfire [dostęp: 1.09.2021].

Klimkowski Ł., Nagy S., Siemek J., 2019, Modele zastępcze wykorzystujące sztuczna inteligencję do sporządzania prognozy wydobycia gazu ze złóż łupkowych, [w:] Nagy S. (red.), Zagadnienia eksploatacji niekonwencjonalnych złóż gazu ziemnego w skałach mułowcowo-łupkowych, Wydawnictwa AGH, Kraków, s. 129-146.

Lee K.C., 2020, Machine Learning 101 - Classification vs. Clustering, https://kevin-clee26.medium.com/machine-learning-101-classification-vs-clustering-e11b12c71243 [dostęp: 1.09.2021].

Mohamed I.M., Mohamed S., Mazher I., Chester P., 2019, Formation Lithology Classification: Insights into Machine Learning Methods, SPE Annual Technical Conference and Exhibition, Calgary, Alberta, Canada, September 2019, SPE-196096-MS. https://doi.org/10.2118/196096-MS.

Nagy S., Barbacki J., Klimkowski Ł., Siemek J., 2019, Wyznaczanie zasobów wydobywalnych na podstawie modeli zastepczych wedtug algorytmu AGH, [w:] Nagy S. (red.), Zagadnienia eksploatacji niekonwencjonalnych złóż gazu ziemnego $w$ skałach mułowcowo-łupkowych, Wydawnictwa AGH, Kraków, s. 166-175.

Navlani A., 2018, KNN Classification using Scikit-learn, https:/www.datacamp.com/ community/tutorials/k-nearest-neighbor-classification-scikit-learn [dostęp: 1.09.2021]. Raschka S., Mirjalili V., 2019, Python Machine Learning: Machine Learning and Deep Learning with Python, scikit-learn, and TensorFlow 2, Packt Publishing.

Russell S.J., Norvig P., 2010, Artificial Intelligence: A Modern Approach, Prentice Hall. Saggaf M.M., Nebrija E.L., 2003, A fuzzy logic approach for the estimation of facies from wire-line logs, American Association of Petroleum Geologists Bulletin, vol. 87(7), s. 1223-1240. https://doi.org/10.1306/02260301019.

Singh H., Seol Y., Myshakin E.M., 2020, Automated Well-Log Processing and Lithology Classification by Identifying Optimal Features Through Unsupervised and Supervised Machine-Learning Algorithms, SPE Journal, vol. 25(05), s. 2778-2800. https:// doi.org/10.2118/202477-PA.

Wolf M., Pelissier-Combesecure J., 1982, FACIOLOG: automated electrofacies determination, SPWLA 23rd Annual Logging Symposium, Corpus Christi, Texas, July 1982, SPWLA-1982-FF.

Xu Ch., Misra S., Srinivasan P., Ma S., 2019, When Petrophysics Meets Big Data: What Can Machine Do?, SPE Middle East Oil and Gas Show and Conference, Manama, Bahrain, March 2019, SPE-195068-MS. https://doi.org/10.2118/195068-MS. 